\section{form $A \wedge A D E$ ENISK}

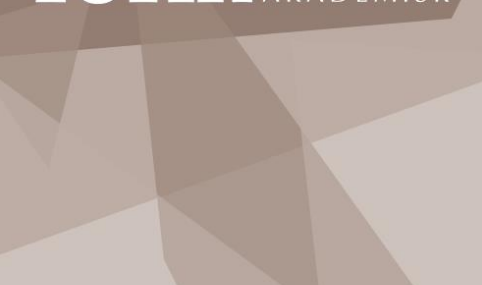

Vol I4, No 2 (202I) https://doi.org/10.7577/formakademisk.4206

Camilla Gåfvels

Senior lecturer, PhD

Konstfack, University of Arts Crafts and Design camilla.gafvels@konstfack.se

Viveca Lindberg

Associate professor, PhD

Stockholm University viveca.lindberg@hsd.su.se

\title{
Theorising craft practices through sketching
}

\author{
The case of Swedish post-compulsory floristry and textile \\ education
}

\begin{abstract}
This article explores how craft practice is theorised through sketching, by comparing narratives about the role of sketching from interviewed Swedish upper secondary textile design and floristry education teachers, and aiming to discern connection to curriculum. The theory and methods used in the article are influenced by Ivor Goodson's work on subject knowledge and curriculum change (1998). Empirical data was obtained from multiple sources, including interviews with four teachers. The findings reveal that, while sketching has been intrinsic to textile design and seamstress vocational knowing for considerable time, sketching is a relatively new phenomenon within floristry vocational knowing and education; essentially dating from the 2011 Swedish educational reform. The discussion claims that sketching provides means to theorise craft practice, through providing an intermediary level between the abstract (theory) and the concrete (objects) within the practice.
\end{abstract}

Keywords:

Seamstress; florist; sketching and drawing; vocation; craft knowing 


\section{INTRODUCTION}

Using theory and methods influenced by Ivor Goodson's (1998) work on subject knowledge and curriculum change, this article aims to discern a connection to curricula in interviewed teachers' narratives about the role of sketching in textile and floristry education in Sweden in order to explore how craft practice is theorised through sketching.

Core aspects of vocational knowing have sensory origins involving tacit dimensions (e.g. Polanyi, 1967). Sketching and drawing have an intrinsic relationship to many of these aspects, particularly to perception within craft practices. Using the examples of seamstress and floristry craft, sensory knowing can be said to precede experiencing the material at hand, be it cloth or flower. Hence, the sensory knowing at use when sketching has the physical materials - not only in focus but also as an 'indispensable point of reference' (Adamson, 2007, p. 42). Thus, sensory knowing is intrinsic to the vocational craft education in question, as participants in the respective crafts are expected to contribute with a subjectivity (e.g. Pink, 2009) that constitutes their understanding of the material, as well as the world at large. All this is reflected in the common saying that to draw is to see, which involves the notion of seeing as a haptic skill (e.g. Grasseni, 2009), a kind of immediate material-based sensitivity towards what is seen.

Overall, sketching/drawing is in this sense a form of intellectual comparative inquiry taking place without being noticed, rather than anything similar to shooting photographs (e.g. Sällström, 1999). Furthermore, sketching is considered a 'way of telling', a way to specify and articulate ideas and content (Ingold, 2013, p. 125). Since intelligibility is a social concept, a person must learn to discern the components of seeing to sketch adequately, in turn promoting more nuanced perception. Therefore, sketching/drawing is a tool for communication. The two specific practices under investigation in this study-contemporary floristry and textile work education-share curricular core content (Skolverket, 2020) concerning communicating ideas and expectations as part of the design process. This implies that a comparison regarding the role of sketching/drawing between these two paths in the overarching handicraft programme of Swedish upper secondary education may prove fruitful.

Birgenstam (2000) explained that sketching aims to search for understanding within a sensible practice, demonstrating knowing that moves beyond imitation of models but which is still situated within the handicraft tradition and its craft practices. The lines of the sketch relate to 'the course of situated actions within specific environmental contexts' (Gunn, 2011, p. 106), regardless of whether the contextual framework is that of seamstresses, florists, architects or artists. Hence, vocational sketching/drawing can tentatively be said to theorise the respective craft practices within different vocations.

Against this backdrop, the following research question has guided the current study: How is floristry and seamstress craft practice theorised in sketching in Swedish upper secondary education?

\section{A historical perspective: Sketching at the core of vocational knowing}

There is relatively little research that specifically focuses on either textile or floristry education (Gåfvels, 2016; Wärvik \& Lindberg, 2018); this is the case in both Swedish and international contexts. Consequently, there is limited research available that explores the historical background of drawing as subject knowledge in either textile or floristry education.

Regarding Swedish floristry education, there has been some research published about its traditions and teaching materials (Gåfvels, 2016, 2018); however, this research does not explore the role of sketching in education. Nonetheless, teaching materials-dating from 1930 and onwardsreveal some indications of how sketching might have been used to develop future florists' sense of proportions (e.g. Ekman, 1934). Floristry education did not become part of the Swedish national upper secondary school system until after $1990^{1}$, which explains the relative absence of official national written sources. However, with the help of local municipal documentation, curricula from the leading floristry school can be traced from the 1940s until the inclusion of floristry education in the Swedish national upper secondary school system in 1990. Before 1990, sketching or drawing was not mentioned in the curricula (of the leading school), but 'colour and form' were (Gåfvels, 2018). 
Concerning textile education, official reports from the Swedish Government (SOU reports) shed light on the historical aspects of formally organised textile education during the first part of the $20^{\text {th }}$ century, as well as its roots, which can be traced at least to the mid-19 ${ }^{\text {th }}$ century (SOU, 1938, p. 49; SOU, 1945, p. 4). All Swedish 'household schools' that provided home management education originally offered textile education. ${ }^{2}$ Some schools specialised in textile education (Broberg, Lindberg, \& Wärvik, 2021), either in sewing - as in the empiric example of the current article-or weaving in combination with other textile handicrafts.

In the official reports, drawing-as a subject within textile education-was emphasised in teacher education for arts and crafts (SOU, 1938, p. 49), as well as in vocational education for household work (SOU, 1945, p. 4). According to these sources, the purpose of the drawing subject was not only to train 'the eye and the hand' but also to contribute to 'forming the sense of colour and shape' (SOU, 1938, pp. 49, 92-93). Two of the more specific Swedish terms used translate as subject-specific drawing ${ }^{3}$ and vocational drawing. ${ }^{4}$ Both these terms were used in relation to fashion and style, as well as to their historical developments.

In previous research, most studies that focused on sketching (as an aspect of drawing) were either interested in craft teacher education or in one of two compulsory school subjects - arts and crafts or, as part of higher education, fine arts or design (Härkki, Seitamaa-Hakkarainen, \& Hakkarainen, 2018; Kyaga, 2017; Räisänen, 2014). Two specific studies about Swedish vocational schools (seamstress craft related to studios for fashion) merit mentioning: Märthaskolan ${ }^{5}$ (Gråbacke, 2015) and Birgittaskolorna 6 (Carlgren, 2016). However, these two studies did not explicitly address issues of teaching, learning and content. Nonetheless, some indications about these issues can be found in both studies, pointing to drawing/sketching as an intrinsic aspect of seamstress education. Similar indications - of drawing as part of the content in late $19^{\text {th }}$-century textile education-have been reported in the Czech Republic context by Kadlec (2019) and in relation to Finland by Heikkilä (2003). Therefore, these indications from previous research suggest that drawing/sketching was identified as being an area of necessary knowledge for seamstresses, even in the early stages of vocational education implementation, both in Sweden and elsewhere. Meanwhile, judging from the available curricula, before 1990, drawing and/or sketching were neither an intrinsic aspect of floristry education nor, judging from historic descriptions of work content, a central aspect of floristry vocational knowing.

\section{Contemporary perspective: In the wake of 2011 reform}

At the time of writing this article in 2020, drawing is a core feature of the Swedish upper secondary handicraft programme, which has included floristry and textile design since 1994:

Teaching in the subject of handicrafts should aim at helping students develop the ability to carry out all stages in the handicraft process from idea to finished product: identifying needs, planning using sketches or drawings, choosing appropriate materials and techniques, carrying out and presenting their work, and analysing and assessing results. (Skolverket, 2020)

Regarding textile design, the contemporary situation is nearly identical to what it was before the last reform, which took place in 2011, both regarding drawing/sketching and other subject matter. The content is similar to how it was before the reform, except regarding computer-based drawing, which was introduced after 2011. In floristry, however, radical changes were made in connection with the 2011 reform, as sketching and technical drawing were included as core content in almost all handicraft courses in the floristry path of the handicraft programme.

\section{Method: Focus at the intersection of schooling history and the history of the individual teacher}

The data used for this article consisted of photographs, film, interviews and policy documents from Swedish upper secondary education in the handicraft programme, the seamstress and floristry streams, respectively. The availability of relevant written sources about textile education-in combination with a corresponding lack of such sources for floristry education-accounts for the different number of teachers interviewed (one textile design teacher ${ }^{7}$ and three floristry teachers) in the two respective 
categories during the data-gathering process. The interview transcripts were translated from Swedish to English. Pauses, laughter, small words and utterances were removed in the process to promote readability. In addition, to further promote readability, minor changes were made to the wording of the quotes included in this article.

The choice to focus on the intersection of schooling history, notably in terms of curriculum development, and the history told by the individual teacher was made under the influence of Ivor Goodson's (1998) work on subject knowledge and curriculum change. The mutual interaction between different levels of influences - as expressed at the more socially pre-established level of curriculum and at the relatively more amenable individual level of the teacher-is intended to enable capturing what the sketching does in its specific context.

In the analytical process, three analytical questions were asked: (1) What assignments are students given where sketching is expected? (2) What is the purpose of these assignments? (3) How do teachers motivate the need for sketching? Based on the answers to these three questions, in combination with the extensive colour-coding of the interview transcripts, themes surfaced (e.g. Braun $\&$ Clarke, 2006) that described the similarities and differences between textile and floristry subject matter in relation to sketching/drawing.

\section{FINDINGS}

The findings are presented separately for textile and floristry education, taking the historical perspective as a starting point.

\section{Seamstress education: Sketching in the Swedish curricula from the 1970s to 2011}

When vocational programmes were integrated into Swedish upper secondary education in 1970 and national curricula were introduced for all programmes, detailed descriptions of the intended objectives and content could be found in the supplements of the syllabuses for each programme. Clothing technology became one of the two-year vocational programmes (Skolöverstyrelsen, 1971a). Drawing continued to be part of the main subject, Clothing technology, which was divided into Work technology and Vocational theory, offering a total of approximately 2,400 hours. Creativity, sense of shape and colour, drawing garments, design and 'security in quickly reproducing simple given shapes' (Skolöverstyrelsen, 1971b, p. 25) are examples of descriptions related to subject-specific drawing during the first year of the programme. For the second year, the drawing of structures of various fabrics, as well as people in motion, complemented the previous content, alongside developing an understanding of contemporary and historical fashion and style. Even though only 60 hours were recommended for subject-specific drawing as one of the listed contents for vocational theory, drawing and sketching were also included in other parts of the syllabuses. An example of intended progress from the first to the second year of the programme is how, during the second year, the design of garments was emphasised as a drawing goal (Skolöverstyrelsen, 1971b). With the reforming of upper secondary education that took place in the 1990s, the duration of all programmes became three years, and the scope was broadened. Textile education was divided into three programmes: an industrial programme that educated youth for the clothing industry, a handicraft programme that was targeted towards a career in tailoring and an aesthetic programme, which was related to theatre and costumes. As previously mentioned, floristry also became part of the Handicraft programme in 1990 (Skolverket, 2000). Since the national curricula simultaneously became partly decentralised at that time, it became possible for local facilitators to complement national courses in relation to regional or local needs. Design became the most prominent feature of these local complements (Lindberg, 2006).

\section{Textile design teacher: Sketching is a central aspect of vocational knowing}

According to the textile design teacher interviewed for this study, ${ }^{8}$ from a formal perspective - not much changed regarding sketching requirements due to the most recent educational reform in 2011. However, sketching has come more into focus for other reasons: 
I feel that in recent years, the sketch has gained prominence. It now has more room in the handicraft process when the pupils are to explain their ideas to me, that is their design ideas, especially since they work with their own design, [...] Few pupils have Swedish as their first language.

From a historic perspective, in the past, pupils were educated to work as seamstresses. Today, they become (textile) designers. ${ }^{9}$ Even if this type of change, from seamstresses to designers, is implemented overnight, it can be expected to unfold gradually. The fact that pupils can communicate through their sketching with relative ease compared to their communicating skills in Swedish has heightened the communicative impact of sketching. Teachers must also gradually become accustomed to an altered normality, both in terms of having students for whom Swedish is not their first language and in terms of an increased focus on creative design as compared to an earlier focus on traditional production, which is perhaps particularly salient when comparing modern practice to the original $19^{\text {th }}$-century household school. Thus, sketching emerges as a fruitful way of communicating ideas (e.g. Ingold, 2013).
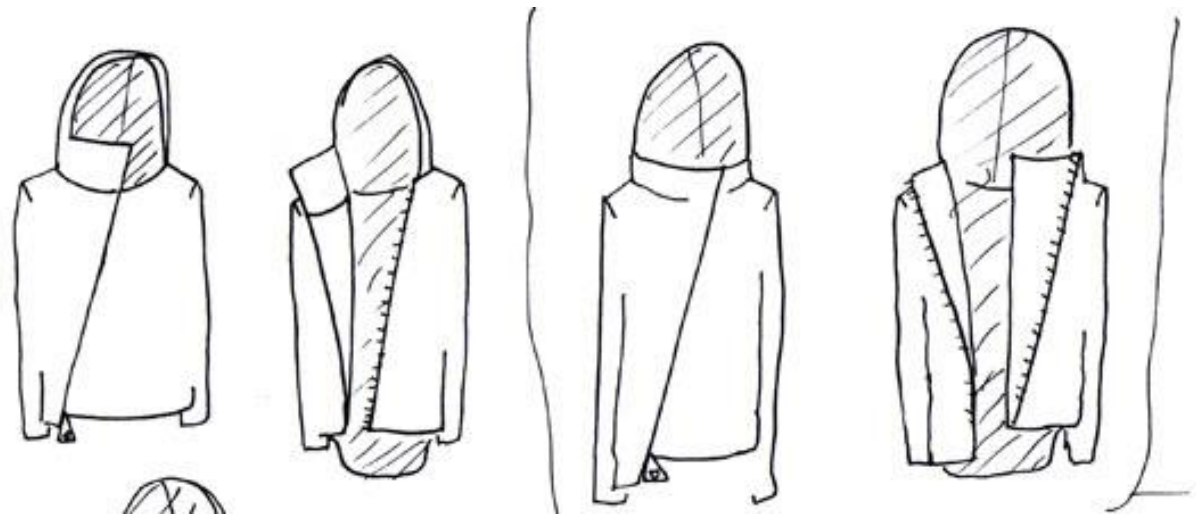

FIGURE 1. Examples of design sketches.
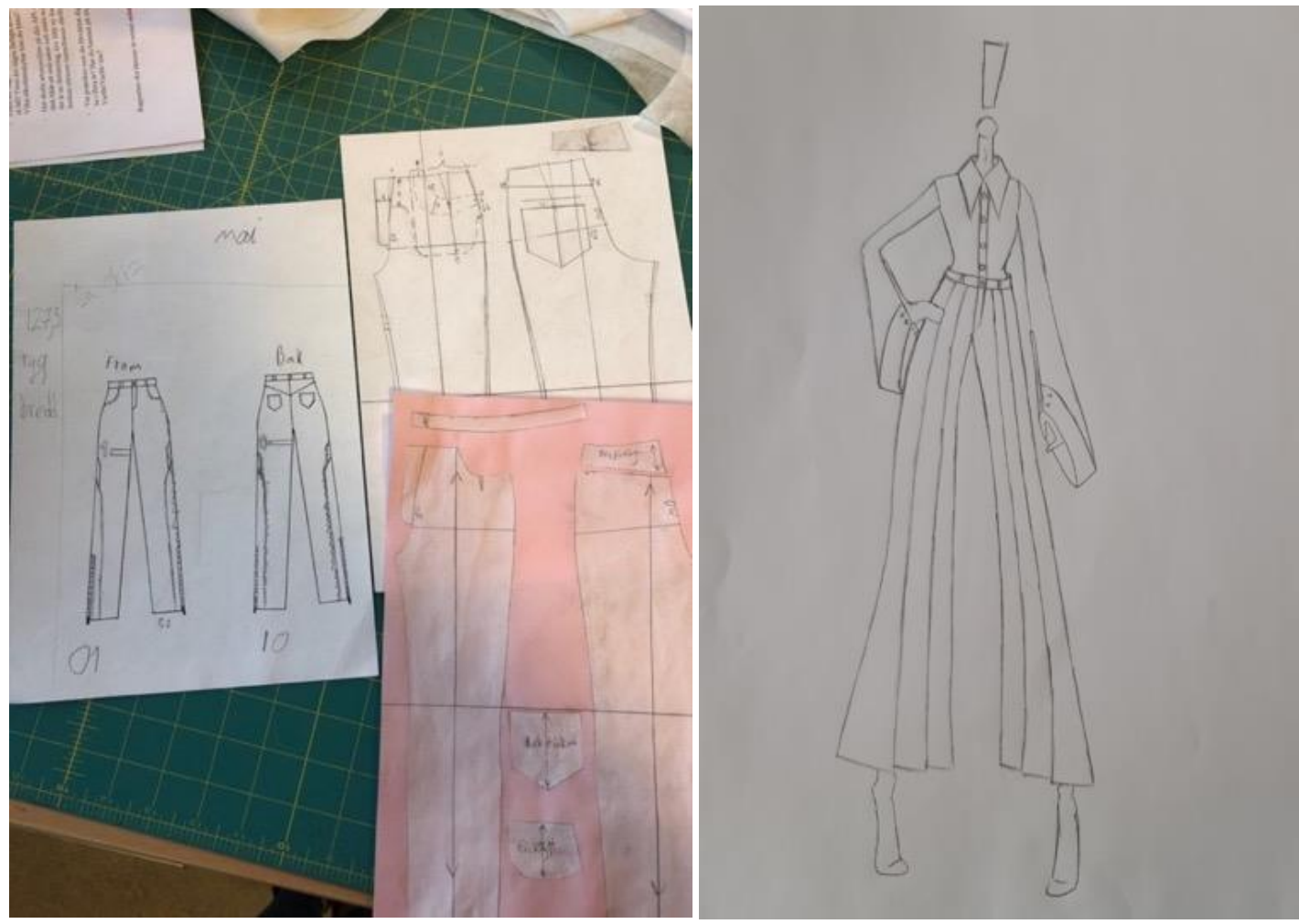

FIGURES 2-3. Garment sketches to the left and a design sketch to the right. 


\section{Extensive sketching practice}

In addition to sketching ideas to communicate them, the teacher described how pupils sketch extensively during their educational trajectory. In the beginning, they are tutored; however, they are expected to become totally independent and capable of creating 'a garment sketch that is presentable to the customer'. This type of sketch is a two-dimensional technical drawing that does not include shading but displays exact proportions, measures, fabric and stitches. Here, the sketch is central to the communicative process. Black ink on white paper is used, and the thickness of the lines corresponds to different types of stitches:

This is something we do with every garment, so they practice sketching [...] they get a lot of practice in technical drawing.

Sketching is a central process when constructing patterns, and students must also be able to analyse sketches from which patterns are constructed. The interviewed teacher emphasised that sketching has always been 'a large part of vocational knowing', again implying that nothing changed regarding sketching at the time of the 2011 reform. However, what has changed-based on an analysis of relevant curricula -is the emphasis on skills related to design and sketching in relation to sewing garments, and consequently, the time spent on each of these skills.
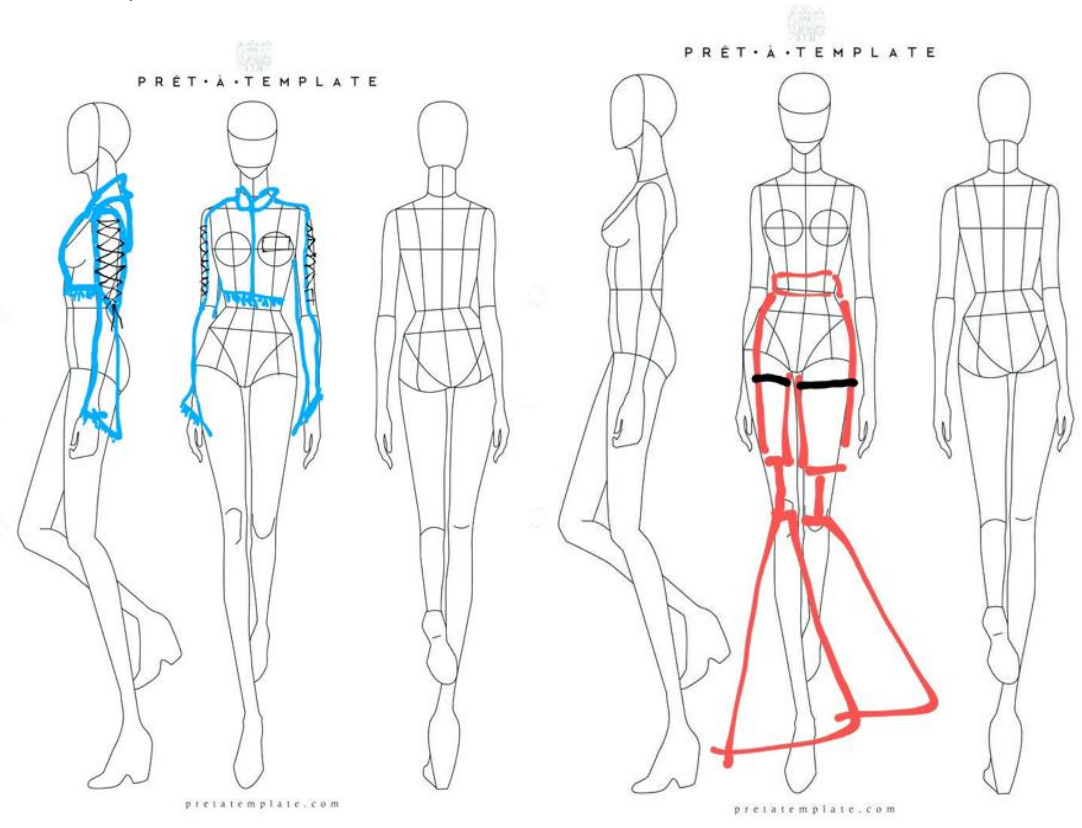

FIGURES 4-5. Computer-based sketches using pre-defined templates.

\section{Difficulties achieving volume}

When asked if there are any recurring problems related to sketching, the teacher highlighted that pupils frequently have difficulties portraying correct volume and find it time-consuming to master proportions:

Proportions is something they get to train a lot.

A different area that some have difficulty mastering is digital technology. However, according to the teacher, the singularly most difficult area is coping with pupils who want their sketches to 'look nice': 
They erase and erase and want exact lines [...] they have trouble letting go.
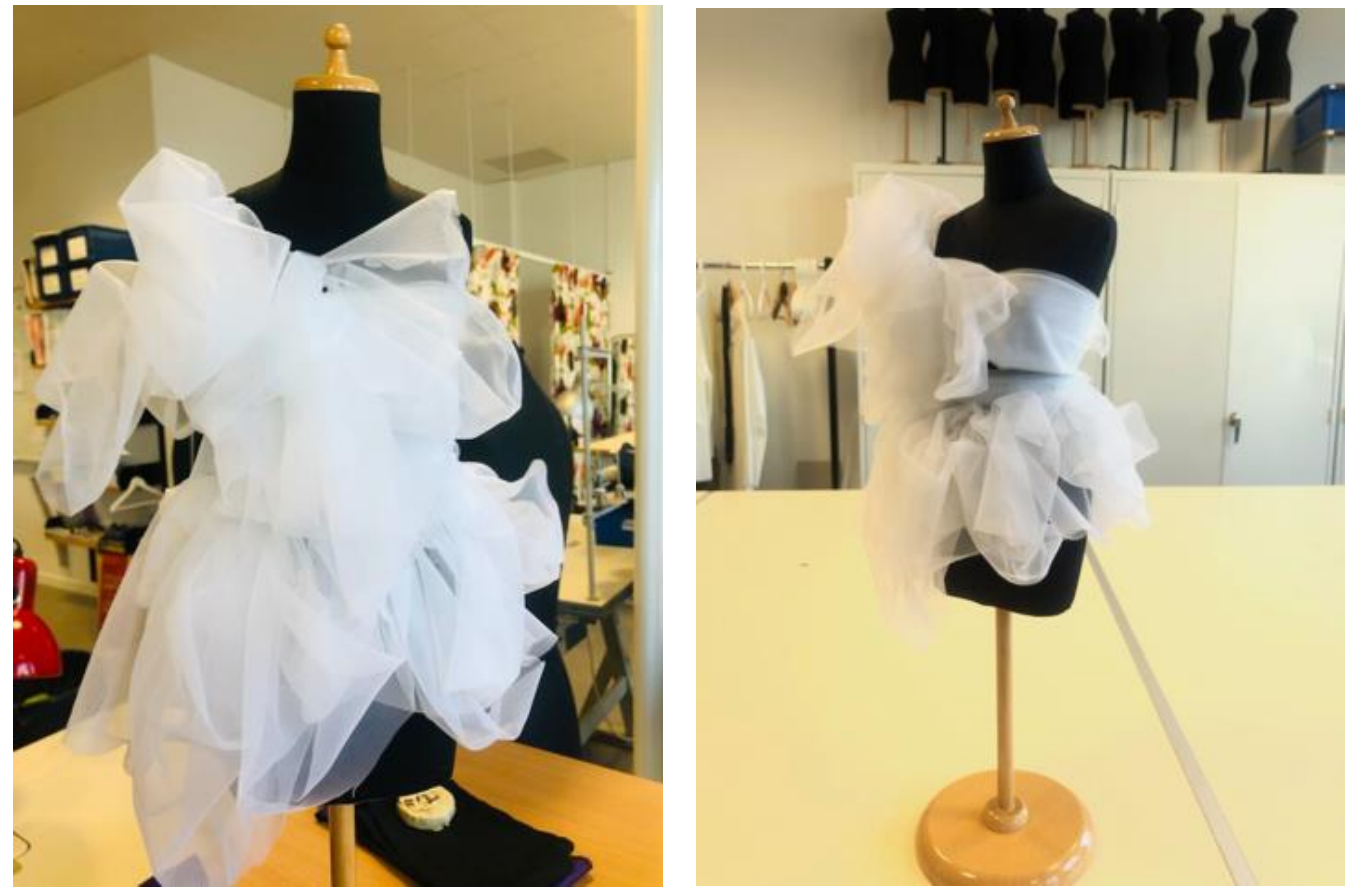

FIGURES 6-7. Two photos of a material sketch-white fabric in the form of top and skirt.

Some students have the opposite problem and are quick to make many elaborate and expressive sketches, without paying enough attention to detail in technical drawing. Pupils need to develop both aspects, according to the interviewed teacher. Later, the teacher explained that there are two main types of sketching in textile design education and described how these two types relate to the problems students experience.

In the handicraft subject, sketching is essentially about quickly portraying a garment with pencil to communicate with me, above all, and an idea. In design subjects, we can start sketching based on something that is not a garment [...] in the first case you usually use white paper from the printer, [but later] when designing you can use whatever material available.
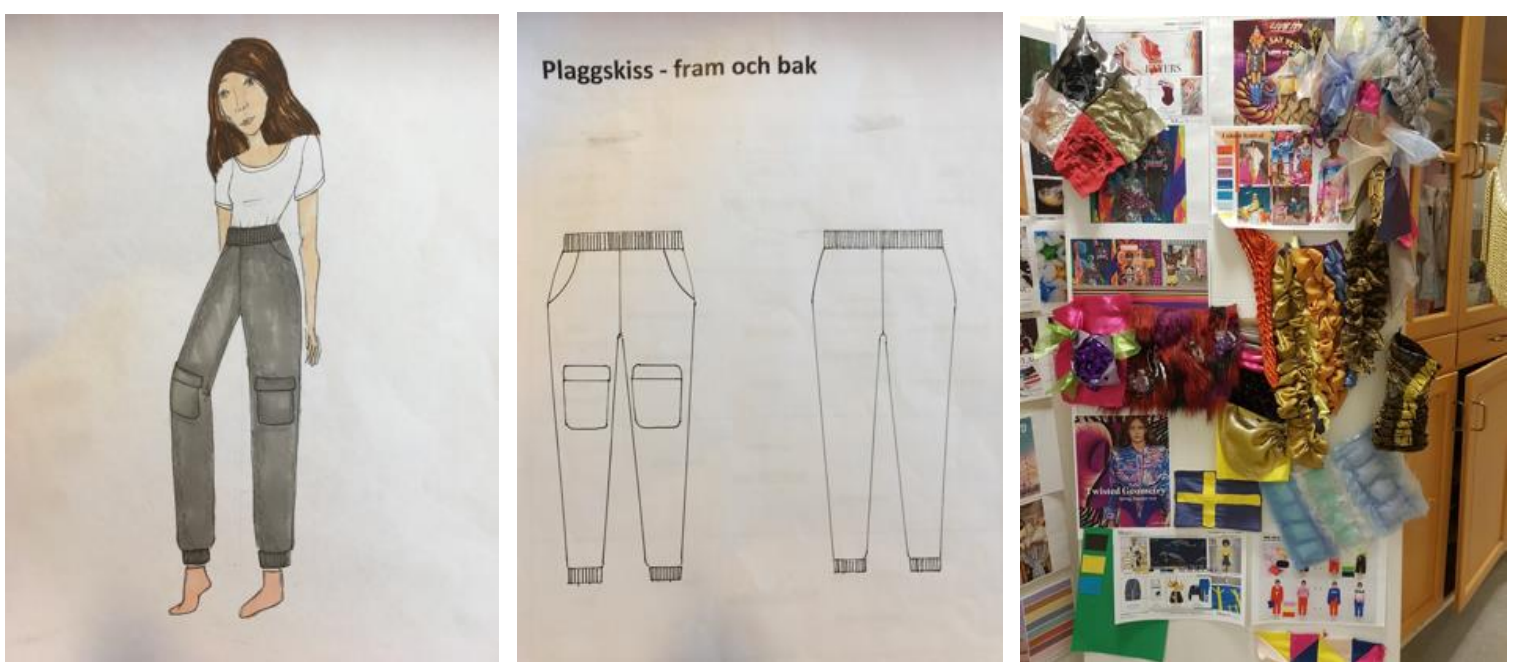

FIGURES 8-10. To the left, a creative design sketch; in the middle, the corresponding garment sketch; to the right, examples of sketching with material. 
In summarising what the interviewed teacher said, sketching is not only intrinsic to the process of textile design but also crucial in garment production, since measurements and the like must be as close to a perfect fit as possible - 'tailor-made'-when a seamstress is involved. Therefore, sketching is a core aspect of textile vocational knowing.

\section{Floristry education: From sketching to portray an idea to sketching to convey an idea}

As previously mentioned, before 1990, drawing and/or sketching were not an intrinsic aspect of floristry education. This situation continued when floristry education became part of the national upper secondary school programme in 1994, except for the inclusion of a mandatory course in art, where sketching was mentioned once as part of the learning goals within the course. The 2011 reform was something radically new - a shift away from traditional vocational knowing and floristry educational history, moving from having one course of 30 hours to having sketching as part of the core content in almost all handicraft floristry courses. Many floristry teachers did not have previous formal training in sketching, implying that even though the reform was implemented overnight, the change has been gradual.
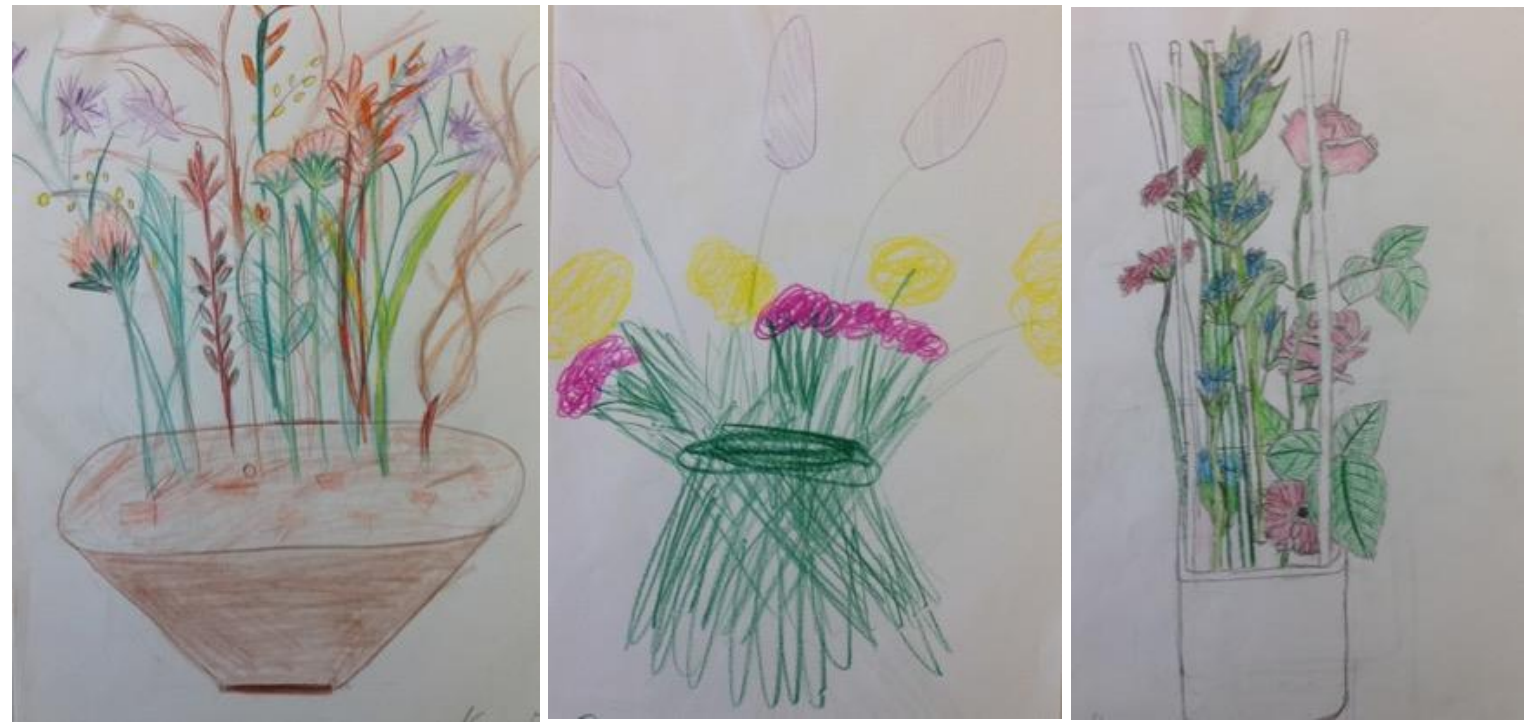

FIGURES 11-13. Three first-year examples of portraying flower arrangements. Note the disproportional pot to the left.

All three interviewed floristry teachers conveyed that sketching did not have a major role in their own vocational educational trajectories, which essentially took place in the early 1990s. One of the teachers said that 'back then', the pupils occasionally made sketches portraying a specific arrangement. In the words of one teacher:

You did not do any sketches [...] and what happened then was essentially that you did not have any idea about what to do when you started, and you always ended up in some kind of problem a bit later, with some ensuing conflict in the arrangement, and then you discussed that with your teacher and were set to start over and so on. [...] There was frequent conflict in the choice of material, form and idea. And of course, you learned that you did those mistakes, and you became aware of that in the work, but now I can catch a glimpse of it already at the sketching stage and discuss it with the pupil.

A clear line of development, which can be discerned in the educational trajectory, is how sketching on paper is relatively absent. However, if one views sketching from a broader-in terms of materialperspective, the statement above can be viewed as an expression of sketching with floristic material, where 'conflicts in material' lead to conversation. Meanwhile, in the older Swedish-language 
educational material in floristry education, from around 1930 (e.g. Ekman, 1934), there are examples of simple sketches providing possible support for consideration of proportions and volume.

\section{More focus on process in contemporary floristry education}

When comparing traditional floristry vocational knowing with the tradition within the textile craft exercised by seamstresses, an organised design and production process -involving different discernible stages -is more immediately evident in the latter case. This is also reflected when the interviewed textile design teacher conveyed-as previously stated-that not much changed regarding sketching following the 2011 educational reform. In contrast, all three interviewed floristry teachers stated, using different wording, that the process has come much more into focus in the wake of the 2011 reform; this is in line with the aim of the Swedish upper secondary handicraft programme quoted in the introduction of this article that mentioned 'stages in the handicraft process from idea to finished product' (Skolverket, 2020).

One of the three floristry teachers mentioned that the move to the current situation has not always been positive, as there is a risk of students missing out on the joy of handling actual materials:

We lose that a little bit as compared to the old days, and there is some of the joy of watching a flower where you see that form emerging and then you place it and think about how to continue building forward and then there is something from inside somehow, and that way you very seldom work nowadays.

The teacher described the difficulty in teaching students how to 'use feeling', which was more in use when there was less focus on process. The teacher explained that there might be two pupils who can work using their 'feeling'; however, the rest of the class, being unable to do so, would lose their confidence if not having clear guidelines to follow, leading to more work for the teacher. The teacher is unable to discuss closely each and every flower arrangement within the temporal limits of education when more than 10 pupils need extensive support; this is contrary to the two talented pupils who were considered able to work using their 'feeling'. The teacher ended by saying:

I can miss what we had [...] that it was possible to go a bit farther out.

As mentioned, all three of the floristry teachers interviewed said that process is much more in focus today than it was 15 years ago and earlier. One of the teachers described sketching as a central component of daily conversations with pupils. However, according to the same teacher-to some extent echoing her previously quoted colleague-emphasising the role of the process in teaching is not always positive:

What can be difficult is that some do not enjoy being so controlled in the process. [...] Perhaps you desire more openness than what we sometimes demand.

According to the same teacher, a different aspect related to issues of 'control' that has become stronger in recent years is how the increasing influence from visual culture, manifested in social media, has begun to exert great influence in the classroom:

When I started, there were not so many pictures to start from, and the pupils come and now want to do exactly like the picture [...] you kind of lose being creative in your own idea. [...] Now, the pupils come and say they want to do this instead of working from a material and watching the material.

Here, the teacher meant that the sketch could serve as a counterweight to trying to copy what someone else has already done. The sketch becomes a tool to develop someone else's ideas.

In summary, it is clear that the focus on process has increased in floristry education following the 2011 educational reform. Meanwhile, it seems that sensory knowing has at least temporarily been deprived of its earlier prominence, since the use of 'feeling' is now less frequent. Furthermore, some 
pupils do not desire the 'feeling' process and simply want their arrangements to look like an Instagram picture. This is to say that the increased prominence of the process is neither without friction nor flawless; it cannot completely replace the traditional way of doing things, and it does not satisfy those pupils looking for a quick fix for their social media channels.

\section{Learning to discern proportions from sketching and then moving on to ideas}

All three floristry teachers interviewed recounted how, to a large extent, the first stage of floristry education involves sketching flowers and that simplifications can be used to make shapes clearer, both in terms of general outer form and the shape of individual flowers. The education about sketching flower shapes can be arranged in different ways, as told by one of the teachers:

[...] simply put, a bit more advanced in order to catch eye of how the flowers look, and then it can be so that we look a lot at outer form simply in order to visually get hold of proportions and maybe also some three dimensional in order to try to get hold of the depth.

At the beginning stages of floristry education, students only need to do simple sketches using carbon pen to portray specific flowers and arrangements, whereas by the end of the third and final year of upper secondary education, the pupils are expected to use their own choice of technique. Furthermore, in the beginning stages, many students have difficulty sketching proportions, as explained by the same teacher, and if they are uncertain, they tend to make 'tiny tiny' sketches.

[...] in the beginning, if they are to draw an arrangement, then they often portray the background or the pot on half of the paper and then there is not enough paper [...] it is a recurring problem, nearly all do that.

During the programme, the students encounter different kinds of sketching and drawing techniques. Successively, they move from sketching in order to portray something to sketching to convey an idea. However, all three teachers described that pupils, even those in the third year, can still experience resistance in their sketches. Furthermore, later on, when they work in flower shops, sketches have less importance than they do in school, primarily serving as a means of communication between customer and florist or between two florists in a shop when, for example, handing over orders. According to the same teacher:

What one wishes is for this process, which takes very much time in school and that we use frequently, to be able to go really quick later when you are out in the working field [...] I can do it in my head, and I can do an analysis really quickly of material and form and kind of material and quickly sketch, and all of the process takes (only) a couple of minutes, whereas we can work with it for half a week (in school with pupils) before they get started.

In line with what was said when summing up the increased focus on process in floristry education, this shows that the process is not fully established within the vocation and that the implementation of the focus on process is driven by educational institutions. There has, of course, always been a process, and the current development is to some extent about formalising and verbalising it. This is a question of moving in the direction of theorisation - in combination with the verbalisation of previously tacit knowing-using a process in which sketching is an important aspect. Below are examples of how sketching has been used following the 2011 educational reform.

\section{Examples of sketching in contemporary floristry education}

When pupils are in their third (and final) year of upper secondary education, they can work towards qualifying for a floristry professional certificate. As part of the examination, pupils must show their work process with the support of sketches. They are asked to show sketches of ideas and techniques and to show that they can mix colours. One of the three interviewed floristry teachers talked about starting a 
collage-like sketching work a couple of years ago after having seen how the pupils could sketch relatively easily using coloured papers instead of flowers.

In parallel with working on their arrangements, students were provided the opportunity to test arranging pieces of coloured paper before and after. The experience gained from working with paper collages is also applicable when using the leaves of flowers on paper.
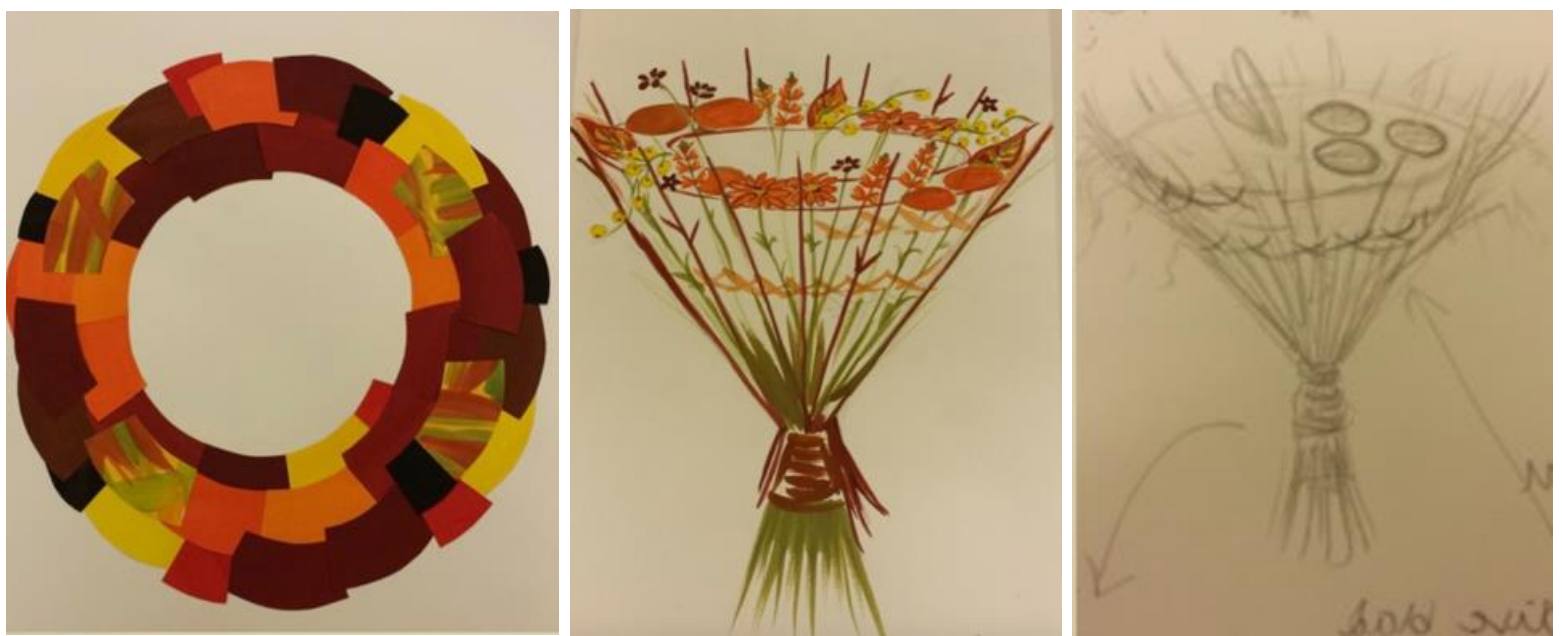

FIGURES 14-16. To the left, a colour sketch of an arrangement from above using pieces of coloured paper; in the middle, the flower arrangement; to the right, a creative first pencil sketch of the same arrangement.
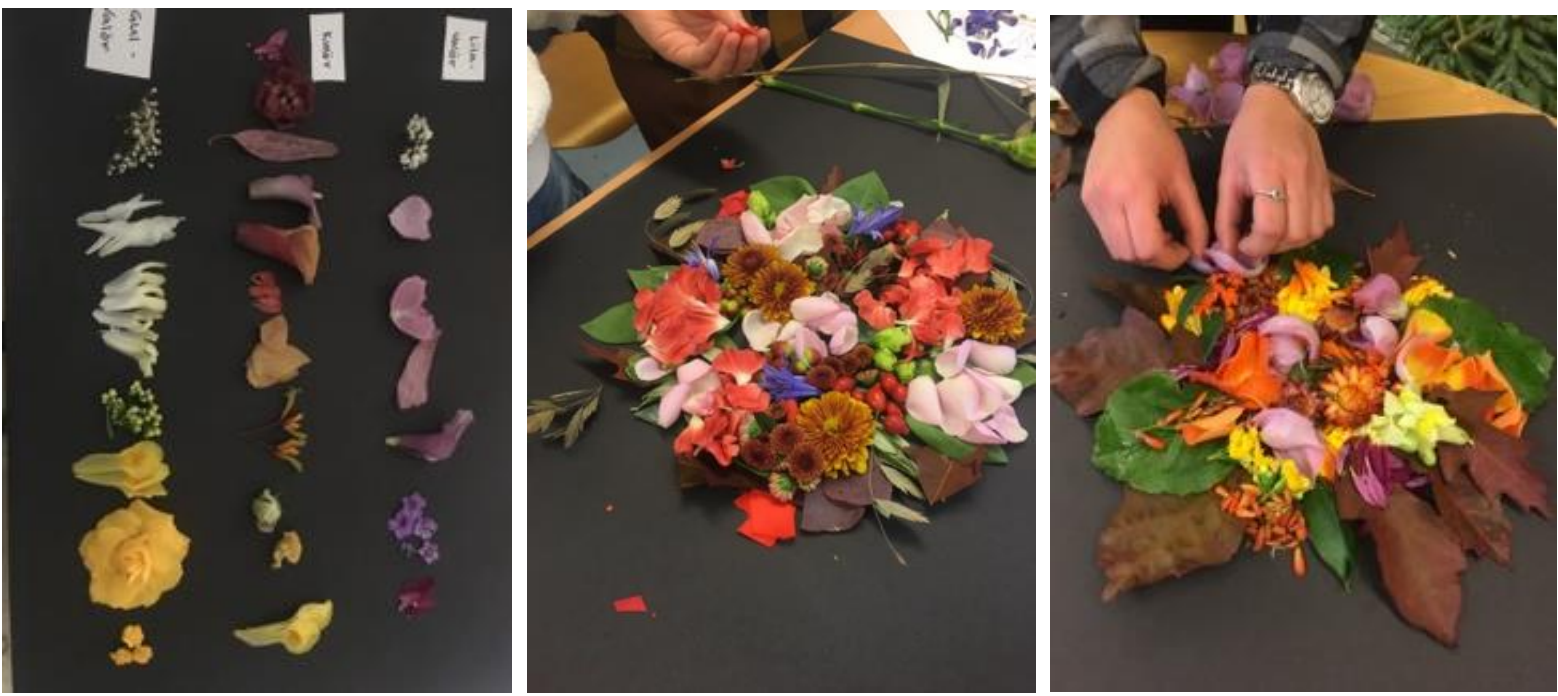

FIGURES 17-19. To the left, different petals organised in colours; in the middle, similar materials in a round form; to the right, another similar round form with petals, foliage and leaves.

The exercise that the pupils performed is about seeing colour; however, the method can be termed a sketch in that it provides the opportunity to 'see' colour in a potential arrangement. Thus, the pupilsinstead of making the actual flower arrangement-arrange and sketch with leaves of flowers or pieces of coloured paper as if completing a flower arrangement.

\section{The look of the sketch is of less importance}

One teacher stressed that it is not important for the sketch to be aesthetically attractive, as long as the teacher can understand what the student means with it. The teacher described never having experienced the need for students to produce more aesthetically attractive sketches, although the two 
other teachers expressed that they appreciate nice pictures. As long as the pupils can meet in dialogue, the aesthetic expression of the sketch is of less importance. One of the teachers said the most important step is the 'quick sketch' since it quickly visualises the pupil's idea and makes it possible to talk about finding alternative solutions. All teachers agreed that the sketch is about developing ideas in flower arrangements and not the sketch itself. However, one of the teachers emphasised that it is 'good' if the pupils sketch on white non-patterned paper and use pencil instead of pen, implying the application of some aesthetic criteria and slightly contradicting the teacher's own earlier statement.

In summarising what the three interviewed floristry teachers said, sketching is about communicating with the teacher and other pupils. Along with an increased focus of process, sketching has become increasingly important following the 2011 educational reform.

\section{DISCUSSION}

\section{Theorising craft practices through sketching?}

The research question that has guided the current study-How is floristry and seamstress craft practice theorised in sketching in Swedish upper secondary education?-deserves as succinct an answer as possible. To summarise what has been revealed in the Findings section, there is a difference in sketching as compared to 'feeling' the material. The sketch offers a kind of distance, a way of seeing from an overarching perspective simultaneously before, during and after the design process, in which the sketch is a tool connecting the different stages. Furthermore, sketching provides a means to theorise craft practice through creating an intermediary level between the abstract (theory) and the concrete (objects) within the practice. This comes as no surprise, given that as soon as ideas in a design process are communicated and/or explained, the situation can be said to constitute-in one way or anothera form of theorising. What is special about the sketch in this context is its role as an intermediary and vehicle of sensory knowing, which potentially becomes visible to others besides the individual crafts(wo)man, thereby conceptualising and displaying more of the crafts(wo)manship than the resulting end product.

Furthermore, as revealed in the findings, both in textile and floristry education, participants communicate with the help of their sketches. This is evident when the textile design teacher explained the central role of the sketch when communicating with students for whom Swedish is not their first language. It should be noted that this is the situation in one specific school in a specific location. The situation might be drastically different in other schools. However, this finding effectively points to the communicative role and potential of sketching.

The above holds true for all communication with the help of sketching, and it is accentuated in situations where more complex ideas are to be conveyed. While a simple statement or question can easily be phrased through a sketch, a sketch is much more helpful when someone needs a mental map or other directions about where/how/why to find something. The garment sketch, as such, can be conceived as a form of map. A similar stance towards sketches can be seen in flower shops when explaining an idea to a customer, when two florists communicate via sketches in combination with a list of flowers or when handing over an order to be expedited later, as in the example provided by one of the interviewed floristry teachers.

Sensory knowing is often difficult to grasp, and it seems this type of tacit knowing is particularly suitable for sketching. Sometimes a few lines represent a direct way to communicate complex ideas or to express some kind of sensitivity related to materials, involving what can be done, how and why. ${ }^{10}$ As mentioned, drawing and sketching do seem to go hand in hand with the central aspects of the (textile) design process. However, regarding floristry education, it is clearer how sketching can be seen as the design process. Thus, sketching stands out as the intellectual effort of going through the bits and pieces of the design process in advance. This became particularly evident in the quote where a floristry teacher commented on sketching and claimed, 'I can do it in my head, and I can do an analysis really quickly'. The sketching process includes theorisation and verbalisation in line with explicit criteria in contemporary curricula, visualising the end product before it emerges and providing room for later reflection about how the plan, product and process relate to each other. Implicit in this way of working is that the end product and prior plan ideally mirror each other and that divergence is to be analysed. 
Therefore, when comparing textile and floristry education, one major difference is the fact that in textile design, sketching and drawing are part of the vocational knowing and have consequently been part of the historical educational content. In floristry education, sketching and technical drawing have only been on the table since the 2011 educational reform. Institutionalisation has already been established within the school context; however, what effect this might have on future floristry vocational knowing is yet to be seen. In terms of Goodson's (1998) terminology, changes within the vocations amount to a level of influence all their own, impacting aspects of vocational knowing. The administrative responsibility for transforming developments within the vocational sectors into courses ${ }^{11}$ belongs to the Swedish National Education Authority, Skolverket, (Lindberg \& Wärvik, 2017). However, regarding sketching and the increased focus on process in floristry education, the change does not come from the sector but from the issued curricula, making the future impact on the sector and its business particularly intriguing.

Formulating ideas in a sketch does not mean producing 'nice' sketches or drawings. Rather, sketching can be seen as a tool to visualise tacit ideas and understandings or to discern development. When using sketches and drawings to communicate an idea or to depict something, both are methods for theorising individual or collective actions, thereby making the actions accessible and intelligible to other people. In summary, vocational sketching theorises the respective craft practices within different vocations.

\section{Concluding remarks}

The difference between the two educational streams - in terms of the communicative role of sketching - can be conveyed with the help of using writing as a metaphor. One can write in full sentences, forming a complete account, intelligible to everyone. Or, one can take notes. The latter convey a full account to the person who has taken notes, but is likely not as intelligible to everyone else. Within textile design, the pupils learn to both take notes and write in full sentences - sketching is intrinsic to the vocational knowing and craft knowing. Within floristry, the pupils primarily learn to take notes. However, these notes are fully understandable to their teacher as well, and in the best case the notes are also understandable to other pupils representing future peers. 


\section{REFERENCES}

Adamson, G. (2007). Thinking through craft. Berg in association with the Victoria \& Albert Museum. https://doi.org/10.5040/9781350036062

Birgerstam, P. (2000). Skapande handling: om idéernas födelse. Studentlitteratur.

Braun, V. \& Clarke, V. (2006) Using thematic analysis in psychology. Qualitative Research in Psychology, 3(2), $77-$ 101. https://doi.org/10.1191/1478088706qp063oa

Broberg, Å. Lindberg, V. \& Wärvik, G-B. (2021). Women's vocational education in Finland and Sweden from 1890 1990: The example of Vocational home economics education. Journal of Vocational Education \& Training, https://doi.org/10.1080/13636820.2021.1889646

Carlgren, M. (2016). Birgittaskolorna. Modeateljéer och sömnadsskolor mellan tradition och förnyelse. [doctoral dissertation, Göteborgs universitet]. Makadam förlag.

Ekman, G. (1934). Blomsterbinderiet genom tiderna: en praktisk handledning jämte kort historisk överblick. Saxon \& Lindström.

Gåfvels, C. (2016). Skolad blick på blommor. Formandet av yrkeskunnande i floristutbildning. Institutionen för pedagogik och didaktik, Stockholms universitet. http://urn.kb.se/resolve?urn=urn:nbn:se:su:diva132660

Gåfvels, C. (2018). Colour and form: Changing expressions of vocational knowing within floristry education. FormAkademisk - forskningstidsskrift for design og designdidaktikk, 11(2), 1-11. https://doi.org/10.7577/formakademisk.1719

Goodson, I., Anstead, C.J. \& Mangan, J.M. (1998). Subject knowledge readings for the study of school subjects. Falmer Press.

Gråbacke, C. (2015). Kläder, shopping och flärd. Modebranschen i Stockholm 1945-2010. Stockholmia förlag.

Gråbacke, C., \& Jörnmark, J. (2008). Den textila modeindustrin i Göteborgsregionen: En kartläggning. http://www.adasweden.se/media/uploads/notice/Textila_modeindustrin_en_rapport.pdf

Grasseni, C. (2009). Skilled Visions: Between Apprenticeship and Standards. Berghahn Books.

Gunn, W. (2009). Learning within the Workplaces of Artists, Anthropologies and Architects: making Stories for Drawings and Writings. In Skilled Visions: Between Apprenticeship and Standards (pp. 106-125). Berghahn Books.

Härkki, T., Seitamaa-Hakkarainen, P. \& Hakkarainen, K. (2018). Line by line, part by part: collaborative sketching for designing. International Journal of Technology and Design Education, 28, 471-494. https://doi.org/10.1007/s10798-016-9379-7

Hauge, A. (2007). Dedicated followers of fashion. An economic geographic analysis of the Swedish fashion industry. (Geografiska regionstudier 76). [Doctoral dissertation, Uppsala universitet]. http://urn.kb.se/resolve?urn=urn:nbn:se:uu:diva-8175

Heikkilä, D. (2003). Käsityön ammatillinen opetus Suomessa 1700-luvulta nykypäiviin. In P. Anttila, D. Heikkilä \& I. Ylönen (Eds.), Suomalaisen käsityökoulutuksen vaiheita 1700-luvulta 2000-luvulle (pp. 7-48). Jyväskylä: Suomen käsityön museo.

Ingold, T. (2013). Making: anthropology, archaeology, art and architecture. Routledge. https://doi.org/10.4324/9780203559055

Kadlec, Petr (2019). Changes in education for textile production in the industrialization process. Vlákna a textile (Fibres and Textiles), 26(4), 32-46. http://vat.ft.tul.cz/2019/4/VaT_2019_4_5.pdf

Kyaga, U. (2017). Swedish Fashion 1930-1960: Rethinking the Swedish Textile and Clothing Industry. [doctoral dissertation, Stockholm University]. http://urn.kb.se/resolve?urn=urn:nbn:se:su:diva-145428

Lindberg, V. \& Wärvik, G-B. (2017). Vad är ett yrkesämne? In A. Fejes, V. Lindberg \& G-B. Wärvik (Eds.), Yrkesdidaktikens mångfald (pp. 23-58). Lärarförlaget.

Lindberg, V. (2006). Contexts for craft and design within Swedish vocational education: implications for the 
content. Tidskrift för lärarutbildning och forskning, 13(2-3), 83-104.

Lindberg, V. (2007). Same syllabus in two contexts: vocational / liberal knowledge? Techne series A: Research in sloyd education and crafts science, A:10, 75-95.

Lindberg, V. (2008). Elevuppgifter inom ett specialutformat program: En fallstudie om förväntningar på elevers kunnande. In K. Borg \& V. Lindberg (Eds.), Kunskapande, kommunikation och bedömning i gestaltande utbildning (pp. 93-105). HLS Förlag.

Pink, S. (2009). Doing sensory ethnography. Sage. https://doi.org/10.4135/9781446249383

Polanyi, M. (1967). The tacit dimension. Doubleday.

Räisänen, R. (2014). How to visualize design? Pupils' experiences of designing in a textile craft project. Craft Research, 5(2), 199-219. https://doi.org/10.1386/crre.5.2.199_1

Sällström, P. (1999). Sinnena ljuger inte. Dialoger.

Skolöverstyrelsen. (1971a). Läroplan för gymnasieskolan, Lgy 70. 1. Allmän del [Curriculum for the upper secondary school, Lgy 70. 1. General part]. Liber Utbildningsförlaget.

Skolöverstyrelsen. (1971b). Läroplan för gymnasieskolan. 2, Supplement. Tvåårig beklädnadsteknisk linje [Curriculum for upper secondary school. 2, Supplement. 2-year clothing technology line]. Liber Utbildningsförlaget.

Skolverket (2000). Gy 2000:08, Hantverksprogrammet: programmål, kursplaner, betygskriterier och kommentarer: [HV]. Statens skolverk.

Skolverket (2020). Hantverksprogrammet. https://www.skolverket.se/undervisning/gymnasieskolan/laroplanprogram-och-amnen-i-gymnasieskolan/gymnasieprogrammen/program?url=1530314731

SOU 1938:49. 1936 års yrkesskolsakkunniga. Betänkandemed förslag angåande utbildningen av lärare i tecning och i slöjd samt för yrkesundervisningen. Ecklesisastikdepartementet.

Wärvik, G-B. \& Lindberg, V. (2018). Integration between school and work: Changes and challenges in Swedish VET 1970-2011. I: S. Choy, G-B. Wärvik \& V. Lindberg (red.). Integration of vocational education and training experiences: Purposes, practices and principles (pp. 279-302). Springer. https://doi.org/10.1007/978981-10-8857-5_15

Wittgenstein, L. (1992). Filosofiska undersökningar. (Ny uppl.) Thales.

\footnotetext{
${ }^{1}$ In relation with upper secondary school reform in the 1990s, and the introduction of the overarching handicraft programme.

${ }^{2}$ Schooling preparing students (women) for a life serving men (at home). Swedish wording: hushållsskola.

${ }^{3}$ Swedish wording: fackteckning.

${ }^{4}$ Swedish wording: yrkesteckning

${ }^{5}$ English translation: the Märtha school.

${ }^{6}$ English translation: the Birgitta schools.

7 The validation of the textile design teacher interview, as well as the overall comparative purpose, benefitted from one of the authors of the current article (Lindberg) having been responsible for data production and reports, including interviews and photographs, related to upper secondary textile education in the project Communication and Learning in Sloyd Practices, funded by the Swedish Research Council 20042008, Dnr 2003-4379.

${ }^{8}$ The results can be validated with data from a previous study about textile design education, where six teachers from two schools participated from 2005 to 2006 (Lindberg, 2007; 2008).

${ }^{9}$ In the 1950s, there were approximately 64,000 employees in the Swedish clothing industry. In 2008, the number of employees had decreased to 1,200, as most of the production had been outsourced to low-salary countries (Gråbacke \& Jörnmark, 2008). Since the design process has remained in Sweden, the industry still needs employees with a textile education. However, the vocational knowing needed has shifted towards design (Hauge, 2007). In other words, whereas the former context for the education of seamstresses was either within the Industrial programme or the Handicraft programme, nowadays Swedish seamstresses tend to be educated within the Aesthetic programme - since 2011 one of the general programmes - where the upper secondary schools label the educational path as either Textile or Fashion design.

${ }^{10}$ Sketching as design also involves a knowledge by acquaintance (Wittgenstein, 1992) with various kinds of material and their properties. Designers may or may not be specialised in specific materials, which has a significant impact on whether the intended design is possible or not. While some material contributes to or even enhance the design, others are counterproductive for the design in that the chosen material does not have the properties that make it possible to realise the intended design.

${ }^{11}$ As well as learning outcomes and core content.
} 